\title{
UNDERWATER OBSERVATIONS ON ROCKS OFF STOKE POINT AND DARTMOUTH
}

\author{
By G. R. Forster \\ The Plymouth Laboratory
}

THE LOWER Limit OF LAMINARIA AND OTHER ALGAE

In the vicinity of the Stoke Point rocks which lie $\frac{1}{4}$ mile offshore, plants of Laminaria-L. hyperborea (Gunn.) Fosl.-disappear below approximately $17 \mathrm{~m}$, from low-water spring tide level. This limit, described in the preliminary note (Forster, 1954, this fournal, Vol. 33, pp. 34I-4) has been confirmed during five dives in the same area in August 1954. The lower limit of Dictyopteris membranacea (Stackh.) Bate, which largely replaces Laminaria, has not yet been fully determined, but in fairly broad gulleys it fades out at $25 \mathrm{~m}$ and is followed by purely animal growths. Twenty-five metres is, therefore, probably close to its lower limit for this particular area.

In contrast, at the East Blackstone which is $\frac{1}{2}$ mile offshore near Dartmouth, the Laminaria only penetrated to 5-6 m. It was followed, down to $8 \mathrm{~m}$, by scattered plants of Dictyota dichotoma (Huds.) Lamour., and very sparse red algae chiefly Heterosiphonia plumosa (Ellis) Batt. Closer inshore, and in Torbay, Saccorhiza polyschides (Lightf.) Batt. apparently replaced the Laminaria hyperborea. The lower limit of Saccorhiza was not observed, but at two separate positions it became very sparse by $6 \mathrm{~m}$. These observations were made during nine dives in September 1954 .

\section{The Sessile Fauna}

The results obtained in 1953 from Stoke Point rocks have been confirmed during 1954 , and further dives made to slightly greater depths. From the end of the Laminaria zone at $17 \mathrm{~m}$ down to $25 \mathrm{~m}$, the rocks are often fairly flat with a series of widely separate ridges about $2 \mathrm{~m}$ high, running roughly north and south. The sea bottom, viewed from 3 or $4 \mathrm{~m}$ away, appeared as a dark brown field of Dictyopteris relieved by large yellow clumps of Cliona celata Grant (non-boring form) and pink sea-fans, Eunicella verrucosa (Pallas). There were roughly two Cliona and three Eunicella colonies per ro sq.m.

Beyond $25 \mathrm{~m}$ the rocks were sometimes irregular, forming gulleys and pockets with a bottom of coarse sand. The gulley walls from 25 to $28 \mathrm{~m}$, though not steeply sloping, were devoid of algae. Here the fauna was composed chiefly of Coelenterata and Bryozoa. Corynactis viridis Allman, though still common, was not as abundant as it was on vertical gulley walls at $18-20 \mathrm{~m}$, when the algae were also excluded. Both Alcyonium glomeratum (Hassall) and 
Epizoanthus wrightii (H. and S.) also occurred frequently, the latter with numerous bright orange and yellow polyps forming patches of up to approximately I sq.m in area. A few colonies of Sertularella gayi (Lamouroux) appeared for the first time, this species being common on the Eddystone trawling grounds in $45^{-65} \mathrm{~m}$. The chief Bryozoa were erect forms, Cellaria fistulosa (L.), Flustra papyracea (Ellis \& Solander), with scattered colonies of Lepralia foliacea (E. \& S.).

The sessile rock fauna at the E. Blackstone was considerably different from that of Stoke Point rocks. From 4.5 to $6 \mathrm{~m}$, very approximately, on vertical or overhanging rock faces small mussels (Mytilus sp.) were abundant. The small white anemone Actinothoë sphyrodeta (Gosse) occurred commonly both with the Mytilus and in patches on its own.

From $6 \mathrm{~m}$ down to $\mathrm{I} 8 \mathrm{~m}$, which was the lower limit reached, the following species were very common: Nemertesia (Antennularia) antennina (L.), Tubularia indivisa L., Sertularella gayi (hydroids); Scrupocellaria scruposa (E. \& S.), Cellaria fistulosa, Flustra papyracea (Bryozoa); and Antedon bifida (Pennant). No zonation of these species with depths was observed; the rock surface being covered over considerable areas either by the hydroids, the Bryozoa, or Antedon or combinations of these groups especially hydroids and Bryozoa. There were also small patches of Actinothoë, groups of Metridium senile (L.), numerous Caryophyllia-C. smithi Stokes, cup coral-and the ubiquitous Corynactis, though only scattered polyps. Only two Eunicella and one Axinella-A. polyploides (Schmidt)-were seen and may, therefore, be taken as rare.

One dive was made at the E. Cod Rock near Berry Head. In contrast to the igneous rock of $\mathrm{E}$. Blackstone, this rock was composed of limestone. At a depth of 6-7 $\mathrm{m}$ the rock surface was honeycombed by the boring mollusc Hiatella arctica (L.). Besides Antedon, Alcyonium digitatum L., and Mytilus sp., which were common, there were also many anemones usually inhabiting Hiatella burrows. The anemones were Tealia felina (L.) and Cereus pedunculatus (Pennant). Metridium was present in smaller numbers and growing normally on the rock.

\section{Discussion}

During the diving the water was found to be much more turbid between Dartmouth and Torbay than near Stoke Point, where during a calm spell of weather the bottom can be seen clearly at a depth of II m, whereas in Torbay even during a prolonged period of offshore winds the comparable limit was only $2-3 \mathrm{~m}$. The shallow penetration of the algae at the E. Blackstone and nearby is clearly the result of growing in more continually turbid water. With the fauna, however, only Sertularella, Flustra and Cellaria were common to both areas. The contrast in the fauna between the two areas was not simply an alteration in the life zones of various species, but the species themselves 
were mostly different. Much of the E. Blackstone fauna was not unfamiliar, since Nemertesia (Antennularia), Actinothoë, Mytilus sp. and Antedon are rather common species in Plymouth Sound. Both the Sound and the Dartmouth-Torbay area are sheltered from the prevailing west and southwest winds, and thus from the more violent wave action; but they also differ from the Stoke Point area in the greater turbidity of the water. Thus the change in the sessile fauna may not be solely related to wave action.

It was surprising to find the sea so much more turbid in the sheltered Dartmouth-Torbay area than in the exposed Stoke Point area, as the reverse had been expected. Although this situation might possibly be attributed merely to the sea-bed being largely mud in Torbay but sand beyond the rocks at Stoke Point, it seems more reasonable to assume that the turbidity does not arise in situ but results from a continual replacement of water containing suspended material. For Torbay itself has extremely weak tidal streams and is very well sheltered from wave action except from the east. In September I954, when the observations were made, there had been no strong east wind for at least two months; so unless the water was being replaced one would expect it to have been much clearer than at Stoke Point where any southwesterly gale turns the sea cloudy for several days. Dr L. H. N. Cooper suggests that the turbidity may originate in the violent water mixing which takes place off Portland Bill, 40 miles to the eastward.

\section{ACKNOWLEDGEMENT}

I am much indebted to Mr R. U. Gooding for his help and assistance both under and above water; to Messrs Siebe Gorman and Co. who were kind enough to loan Mr Gooding apparatus; and to the Royal Society for a grant with which much of my own apparatus was obtained.

\section{SUMMARY}

A description is given of the commonest sublittoral algae and sessile animals found on rock at Stoke Point Reef and at the E. Blackstone rock near Dartmouth to a maximum depth of $28 \mathrm{~m}$. The E. Blackstone fauna resembled that of Plymouth Sound. The marked change which has been found is ascribed to the greater turbidity of the water near Dartmouth and the increased shelter from wave action. 